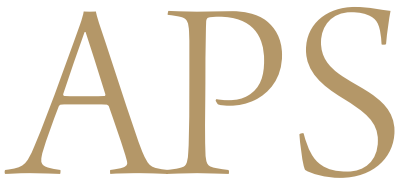

Archives of Plastic Surgery

\title{
Personal Factors that Affect the Satisfaction of Female Patients Undergoing Esthetic Suture after Typical Thyroidectomy
}

\author{
Hyo Young Kim ${ }^{1}$, Jung Won Kim², Jin Hyung Park ${ }^{1}$, Jung Hun Kim ${ }^{3}$, Yea Sik Han ${ }^{1}$ \\ Departments of ${ }^{1}$ Plastic Surgery, ${ }^{2}$ Occupational and Environment Medicine, and ${ }^{3}$ Surgery, Kosin University Gospel Hospital, Kosin University \\ School of Medicine, Busan, Korea
}

Background In esthetic surgery, understanding the factors that influence patient satisfaction is important for successful practice. We hypothesize that the factors that influence patient satisfaction include not only aesthetic and functional outcomes, but also personal factors such as the level of familiarity with factors affecting wound healing and expectations regarding aesthetic outcome.

Methods One hundred patients who underwent esthetic closure after thyroidectomy were included in this study. In order to evaluate the individual characteristics of the patients, a preoperative survey was administered to the patients. We estimated the patient satisfaction six months postoperatively and assessed the aesthetic and functional outcomes using the Patient and Observer Scar Assessment Scale.

Results According to the results of correlation analysis, level of familiarity with wound healing factors had a positive correlation with satisfaction. High expectations, pain, itching, and high observer scale score had negative correlations with satisfaction. The factors that were correlated with satisfaction were included in the multiple regression analysis. Level of familiarity with wound healing factors was found to have a positive relationship with satisfaction, while itching and observer scale were found to have a negative relationship with satisfaction. After excluding 10 patients who had hypertrophic scars, only level of familiarity with wound healing factors and expectations affected satisfaction.

Conclusions The level of familiarity with factors affecting wound healing and expectations were found to independently affect satisfaction. Improving patients' level of familiarity with wound healing factors and reducing their expectations by providing suitable preoperative education has the potential to improve patient satisfaction.

Keywords Personal satisfaction / Esthetics / Surgery, plastic

\author{
Correspondence: Yea Sik Han \\ Department of Plastic Surgery, \\ Kosin University Gospel Hospital, \\ Kosin University School of Medicine, \\ 262 Gamcheon-ro, Seo-gu, Busan \\ 602-702, Korea \\ Tel: +82-51-990-6131 \\ Fax: +82-51-990-3034 \\ E-mail: Hanplastic1@naver.com
}

This article was presented at the 70th Congress of the Korean Society of Plastic and Reconstructive Surgeons on November 10, 2012 in Seoul, Korea.

No potential conflict of interest relevant to this article was reported.

Received: 13 Mar 2013 • Revised: 28 May 2013 • Accepted: 4 Jun 2013

pISSN: 2234-6163・elSSN: 2234-6171 • http://dx.doi.org/10.5999/aps.2013.40.4.414・Arch Plast Surg 2013;40:414-424

\section{INTRODUCTION}

Unlike other fields of medicine that use mortality and morbid- ity rates as a basis for evaluation, patient satisfaction is an important factor in plastic surgery, one that affects quality of life $[1,2]$. Therefore, it is important to understand the factors that affect

Copyright $(\odot 2013$ The Korean Society of Plastic and Reconstructive Surgeons

This is an Open Access article distributed under the terms of the Creative Commons Attribution Non-Commercial License (http://creativecommons.org/

licenses/by-nc/3.0/) which permits unrestricted non-commercial use, distribution, and reproduction in any medium, provided the original work is properly cited. 
the level of patient satisfaction. Understanding these factors may give doctors an opportunity to implement changes to reduce the conditions that adversely influence patient satisfaction.

In plastic surgery, some patients show dissatisfaction despite good aesthetic results. Some patients are dissatisfied due to psychiatric problems, but in most cases, the correlation between patient dissatisfaction and mental condition has not been understood clearly [3]. The authors have experienced low patient satisfaction with esthetic suture in thyroidectomy through transverse cervical incision, even though they were objectively assessed as having had good esthetic results. The authors believed other factors could have influenced patient satisfaction with cosmetic surgery. According to a literature review on patient satisfaction [4], a total of 122 studies on functional and cosmetic aspects as well as all other issues have been reported. Most of the studies were on patients' feelings of satisfaction; however, there were no studies on patients' preoperative levels of familiarity with wound healing factors and patient expectations that influence on the patient satisfaction.

In this study, personal factors that affected the satisfaction levels of patients who underwent esthetic suture in the course of a thyroidectomy through a transverse cervical incision were investigated. The purpose of this study was to identify personal factors that influence patient satisfaction and to provide patients with an appropriate explanation and education before their surgery in an attempt to enhance the level of patient satisfaction.

\section{METHODS}

\section{Study subjects}

A total of 100 female patients who underwent a thyroidectomy through transverse cervical incision and esthetic suture, performed by the same surgeon between October 2010 and June 2011, were selected for participation in this study. Preoperatively and six months postoperatively, they completed surveys. When they visited the Plastic Surgery Department of the authors' hospital as outpatients before their surgery, they were informed that the suture, the so-called 'esthetic suture,' might be used for cosmetic purposes. Any patients 15 years old or younger, 60 years old or older, or those who had a history of thyroid cancer surgery at the same site or of radiation therapy were excluded from this study.

\section{Study methods}

Surveys preoperatively and six months postoperatively

A questionnaire on the personal factors that are thought to influence patient satisfaction levels was designed and administered before the surgery (Fig. 1). The items in the questionnaire in-

\section{Fig. 1. A preoperative questionnaire: personal factor assessment form}

Demographic factors, the level of familiarity with factors affecting the wound healing process, the reasons for deciding to undergo esthetic suture, and level of expectation regarding the results were assessed.

※ Please indicate your status.

1) Sex : male (), female( )

2) Age: 10-19( ), 20-29( ), 30-39( ), 40-49( ), 50-59( )

3) Educations: Elementary school( ), middle School( ), high school( ), university ( )

4) I have undergone plastic surgery before. ( )

I have never undergone plastic surgery. ( )

5) Medical history: Diabetes ( ), high blood pressure( ), hepatitis ( ), tuberculosis ( ),

hypothyroidism ( ), hyperthyroidism ( )

6) Scars from wounds

I usually have little scarring from wounds. ( )

I usually have some noticeable scars from wounds. ( )

I scar severely and I think these scars are keloid. ( ) 


\section{Fig. 1. A preoperative questionnaire: personal factor assessment form}

(continued from the previous page)

2. Did you realize the following factors might influence healing after closure?

\begin{tabular}{|c|c|c|}
\hline & I realize & I did not realize \\
\hline $\begin{array}{l}\text { Technique of wound closure } \\
\text { (Plastic surgeon vs. general surgeon) }\end{array}$ & & \\
\hline Postoperative wound care & & \\
\hline Time in operation room & & \\
\hline Patient's constitution & & \\
\hline Neck exercise after surgery & & \\
\hline Comorbidity (e.g., DM) & & \\
\hline Location and length of scar & & \\
\hline Physical damage during operation & & \\
\hline $\begin{array}{l}\text { Ischemic injury, infection, foreign } \\
\text { bodies }\end{array}$ & & \\
\hline Edema/elevated tissue pressure & & \\
\hline Age & & \\
\hline Hypothermia and pain & & \\
\hline $\begin{array}{l}\text { Hepatic failure, renal failure } \\
\text { respiratory failure }\end{array}$ & & \\
\hline Nutrition & & \\
\hline Smoking & & \\
\hline Corticosteroids & & \\
\hline Ionizing radiation and chemotherapy & & \\
\hline
\end{tabular}

cluded the following: 1) the familiarity level with factors affecting the wound healing process, 2) the expectation level of the results, 3) the reasons for deciding to undergo esthetic suture after thyroidectomy, and 4) demographic factors such as the patient age and education level. For evaluating the familiarity level with factors affecting the wound healing process, 17 factors that could influence the healing process were selected [5], and the patients were asked to select the factors recognized before the survey. At six months postoperatively, the patients' satisfaction levels were evaluated (Fig. 2).

Evaluation of other factors that may influence patient satisfaction

To maintain the consistency of the survey, preoperative explana- 


\section{Fig. 1. A preoperative questionnaire: personal factor assessment form}

(continued from the previous page)

3. What is the main factor influencing your decision to undergo cosmetic suture?

a. Seeing other patients' scars after surgery

b. My expectations regarding plastic surgical suture

c. The recommendation of the charge doctor

d. The recommendation of family or friends

e. Others

(reason)

4. Please indicate what expectations you have regarding cosmetic suture on a scale of 0 to

100. (Indicate your expectation as a number, such as 25 or 80 .)

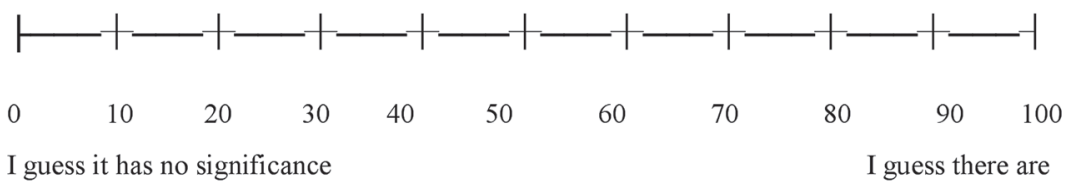

no scars after cosmetic suture

5. Were you satisfied with the explanation from the medical staff?

If the explanation was not sufficient, please indicate what could be done to improve the experience

a. I am satisfied with the explanation given.

b. I need more information

tions were made by the same doctor in the same amount of time using the same consent form. Through an additional item on the questionnaire, which asked whether the doctor's explanation was sufficient, the effects of the preoperative explanation were investigated. To evaluate the influence of the esthetic results on the satisfaction level, two plastic surgeons performed scar evaluations using the Patient and Observer Scar Assessment Scale (POSAS) at six months postoperatively (Fig. 3). To evaluate the influence of the functional results, including pain and itching sensations, on the overall satisfaction level, part of the patient scar scale in the POSAS was added to the survey that was conducted six months postoperatively (Fig. 2).

\section{Statistical analysis}

A statistical analysis was conducted using SPSS ver. 18.0 (SPSS,
Inc., Chicago, IL, USA). The correlation between the personal factors in the preoperative evaluation and the postoperative satisfaction level was analyzed. After selecting statistically significant variables in the correlation, a multiple regression analysis was conducted using the postoperative satisfaction level as a dependent variable. In all the statistical comparisons, significance was recognized with a P-value less than 0.05 .

\section{RESULTS}

\section{Survey results}

\section{Demographic analysis results}

The results of the demographic analysis are shown in Table 1. The number of the subjects in each age group was as follows: 41 (41\%) in their 40s, 24 (24\%) in their 30s, 23 (23\%) in their 50s, 


\section{Fig. 2. A postoperative survey was performed}

The patient satisfaction level and functional results were evaluated at six months postoperatively.

1 . Were you satisfied with the aesthetic results?

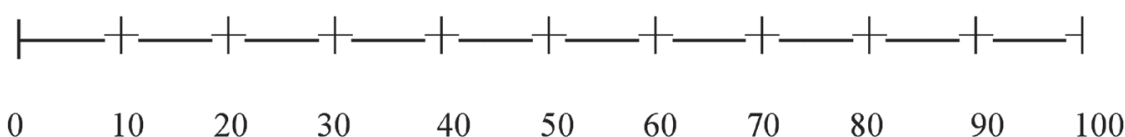

(No, not at all)

(Yes, very much)

1) If you were not satisfied, what is the reason? (You can choose more than one.)

If you were not satisfied, what is the reason?
a. Too many scars remaining
b. Insufficient explanation from the medical staff
c. Too expensive
d. I think the results are no different from the results of general surgical suture
e. Other ( )

2. Has your scar been painful for the past few weeks?

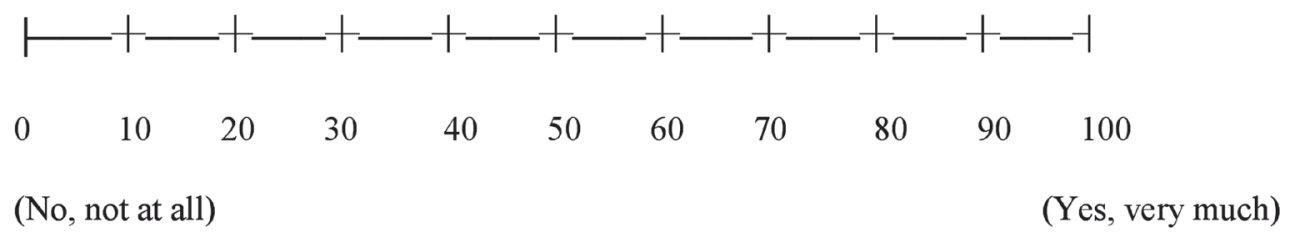

3 Has the scar been itching for the past few weeks?

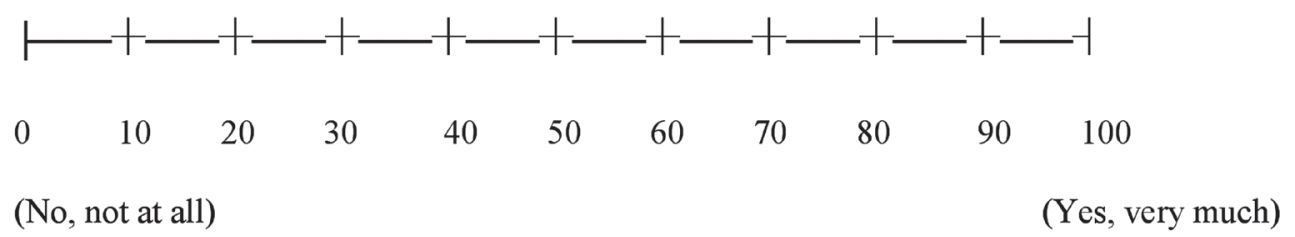

$9(9 \%)$ in their 20 s, and $3(3 \%)$ in their teens. The mean age was $42.61 \pm 11.20$ years. Most of the patients were high school graduates (41 subjects), followed by college graduates (39), middle school graduates (10), and elementary school graduates (6). Sixty-three subjects had no previous cosmetic surgery experience, and 33 had previous cosmetic surgery experience. Most of 


\section{Fig. 3. Observer scales for evaluating cosmetic results}

Linear surgical scars were assessed to evaluate vascularity, pigmentation, thickness, relief, pliability, and surface area.

\begin{tabular}{|c|c|c|c|c|c|c|c|c|c|c|c|c|c|}
\hline & & Normal skin & 1 & 2 & 3 & 4 & 5 & 6 & 7 & 8 & 9 & 10 & $\begin{array}{l}\text { Worst scar } \\
\text { imaginable }\end{array}$ \\
\hline \multirow{5}{*}{ Vascularity } & Pale & & & & & & & & & & & & \\
\hline & Pink & & & & & & & & & & & & \\
\hline & Red & & & & & & & & & & & & \\
\hline & Purple & & & & & & & & & & & & \\
\hline & Mix & & & & & & & & & & & & \\
\hline \multirow{3}{*}{ Pigmentation } & Нуро & & & & & & & & & & & & \\
\hline & Hyper & & & & & & & & & & & & \\
\hline & Mix & & & & & & & & & & & & \\
\hline \multirow{2}{*}{ Thickness } & Thicker & & & & & & & & & & & & \\
\hline & Thinner & & & & & & & & & & & & \\
\hline \multirow{3}{*}{ Relief } & More & & & & & & & & & & & & \\
\hline & Less & & & & & & & & & & & & \\
\hline & Mix & & & & & & & & & & & & \\
\hline \multirow{3}{*}{ Pliability } & Supple & & & & & & & & & & & & \\
\hline & Stiff & & & & & & & & & & & & \\
\hline & Mix & & & & & & & & & & & & \\
\hline \multirow{3}{*}{ Surface area } & Expansion & & & & & & & & & & & & \\
\hline & Contraction & & & & & & & & & & & & \\
\hline & Mix & & & & & & & & & & & & \\
\hline \multicolumn{2}{|c|}{ Overall opinion } & & & & & & & & & & & & \\
\hline
\end{tabular}

the patients did not have a history of any disease (76 subjects), and 6 subjects had suffered from hyperthyroidism and 5 from hypothyroidism. In addition, 50 subjects answered that their scars normally disappeared easily, 45 subjects answered that their scars remained noticeable, and 5 subjects answered that they had keloid lesions. 


\section{Table 1. Demographic analysis}

\begin{tabular}{|c|c|}
\hline Item & Percentage $(\%)$ \\
\hline \multicolumn{2}{|l|}{ Age (yr) } \\
\hline $10-19$ & 3 \\
\hline $20-29$ & 9 \\
\hline $30-39$ & 24 \\
\hline $40-49$ & 41 \\
\hline $50-59$ & 23 \\
\hline \multicolumn{2}{|l|}{ Education } \\
\hline Elementary school diploma & 6 \\
\hline Middle school diploma & 10 \\
\hline High school diploma & 41 \\
\hline Four-year college degree & 39 \\
\hline No response & 4 \\
\hline \multicolumn{2}{|l|}{ Previous plastic surgery } \\
\hline Yes & 33 \\
\hline No & 63 \\
\hline No response & 4 \\
\hline \multicolumn{2}{|l|}{ Comorbidity } \\
\hline Diabetes & 2 \\
\hline High blood pressure & 5 \\
\hline Hepatitis & 2 \\
\hline Tuberculosis & 2 \\
\hline Hypothyroidism & 5 \\
\hline Hyperthyroidism & 6 \\
\hline None & 76 \\
\hline No response & 2 \\
\hline \multicolumn{2}{|l|}{ Scars from wounds } \\
\hline I usually have little scarring from wounds & 50 \\
\hline I usually have some noticeable scars from wounds & 45 \\
\hline I scar severely and I think these scars are keloid & 3 \\
\hline No response & 2 \\
\hline
\end{tabular}

Evaluation of the level of familiarity with factors affecting the wound healing process, reasons for choosing esthetic suture, and mean level of expectation regarding the results of the esthetic suture

The numbers of subjects who recognized the factors that affected their wound healing process by item were as follows: 93 recognized the suture method; 86 , postoperative wound care; 75 , the location and length of the incision; 69 , age; 55, nutritional condition; 54, ischemic damage, foreign objects, infection, and inflammation; 53, physical tissue damage during the surgery; 51, the uniqueness of their physical constitution (i.e., keloids); 46, practice of postoperative neck exercise; 44, edema immediately after the surgery; 43 , operation time; 35 , chronic diseases such as diabetes; 34 , smoking; 33 , intake of drugs such as steroids and hormones; 33 , postoperative radiation and chemotherapy; 20, hypothermia and pain; and 17, liver, kidney, and respiratory failure. The mean number of factors recognized preoperatively as influencing the wound healing process was $8 \pm 4.1$ (Table 2).

Most (40) of the subjects decided to undergo esthetic suture due to their expectations, followed by the recommendations of their doctors (20), the results of other patients (14), and the recommendations of their family and acquaintances (9) (Table 3).

The mean expectation level with regard to the results of the esthetic suture was $73.5 \pm 24$.1. Sixty-five subjects reported that the doctor's preoperative explanation was sufficient, whereas 34 subjects responded that it was insufficient (Table 4).

Table 2. Analysis of patient's level of familiarity with factors that affect wound healing

\begin{tabular}{|c|c|c|c|c|c|}
\hline Item & Yes & No & No response & $\begin{array}{l}\text { No. with a preoperative } \\
\text { familiarity with factors }\end{array}$ & Patient No. \\
\hline $\begin{array}{l}\text { Technique of wound closure } \\
\text { (plastic surgeon vs. general surgeon) }\end{array}$ & 93 & 5 & 2 & With 0 & 1 \\
\hline Postoperative wound care & 85 & 12 & 3 & With 1 & 3 \\
\hline Time in operation room & 43 & 55 & 2 & With 2 & 2 \\
\hline Patient's constitution & 51 & 47 & 2 & With 3 & 4 \\
\hline Neck exercise after surgery & 46 & 49 & 5 & With 4 & 11 \\
\hline Comorbidity & 35 & 61 & 4 & With 5 & 7 \\
\hline Location and length of scar & 75 & 21 & 4 & With 6 & 5 \\
\hline Physical damage during operation & 53 & 44 & 3 & With 7 & 6 \\
\hline Ischemic injury, infection, foreign bodies & 54 & 44 & 2 & With 8 & 14 \\
\hline Edema/elevated tissue pressure & 44 & 54 & 2 & With 9 & 11 \\
\hline Patient age & 69 & 29 & 2 & With 10 & 7 \\
\hline Hypothermia and pain & 20 & 79 & 1 & With 11 & 2 \\
\hline Hepatic failure, renal failure, respiratory failure & 17 & 80 & 3 & With 12 & 4 \\
\hline Nutrition & 55 & 42 & 3 & With 13 & 7 \\
\hline Smoking & 34 & 65 & 1 & With 14 & 6 \\
\hline Corticosteroids & 33 & 65 & 2 & With 15 & 3 \\
\hline Ionizing radiation and chemotherapy & 33 & 65 & 2 & With 16 & 3 \\
\hline Total & 840 & 817 & 43 & With 17 & 4 \\
\hline
\end{tabular}


Satisfaction level with the postoperative esthetic suture and pain and itching sensation scores

The satisfaction level with the postoperative esthetic suture was $58.9 \pm 24$, the pain score was $15.3 \pm 22.1$, the itching sensation score was $15.2 \pm 21.7$, and the observer scale was $17 \pm 3.5$ (Table 5).

\section{Correlation analysis}

The correlation analysis showed that the coefficient of the correlation between the familiarity level with wound healing factors and the satisfaction level was 0.28 , which revealed a significant

\begin{tabular}{|c|c|}
\hline $\begin{array}{l}\text { Main factor influencing decision } \\
\text { to undergo cosmetic suture }\end{array}$ & Percentage $(\%)$ \\
\hline Seeing other patients' scars after surgery & 14 \\
\hline Expectations regarding plastic surgical suture & 40 \\
\hline The recommendation of the attendingdoctor & 20 \\
\hline The recommendation of family or friends & 9 \\
\hline Other & 13 \\
\hline No response & 4 \\
\hline
\end{tabular}

Table 4. Analysis of preoperative expectations and whether there was sufficient explanation from the medical staff

\begin{tabular}{lc|}
\hline Variable & Value \\
\hline Expectations that you have regarding cosmetic suture & $73.45 \pm 24.19$ \\
Expectations (VAS score) & $(0-100)$ \\
Were you satisfied with the explanation from the medical staff? & \\
I am satisfied with the explanation given & 65 \\
I need more information & 34 \\
No response & 1 \\
\hline Values are presneted as mean \pm standard deviation (range) or percen- \\
tage. \\
VAS, visual analogue scale. \\
\hline
\end{tabular}

positive correlation $(\mathrm{P}<0.01)$. The coefficients of the correlations between the satisfaction levels and the respective expectation levels, pain sensation, itching sensation, and observer scales were $-0.286,-0.272,-0.342$, and -0.302 , respectively, which all showed significant negative correlations $(\mathrm{P}<0.01, \mathrm{P}<0.01$, $\mathrm{P}<0.05$, and $\mathrm{P}<0.01$, respectively). The absolute correlation coefficient value of the itching sensation was the highest, followed by those of the observer scale, pain, expectation regarding the results, and level of familiarity with wound healing factors. Since the correlation coefficient of having an itching sensation and pain was quite high at 0.611 , multicollinearity was a clinical possibility. Accordingly, pain, which had a low correlation coefficient, was excluded from the multiple regression analysis. No significant correlations were observed between the satisfaction level and demographic factors, such as age or education level, nor with the reasons for deciding to undergo cosmetic surgery (Table 6).

\section{Multiple regression analysis}

As a univariate analysis, a multiple regression analysis was conducted using statistically significant variables, including the familiarity with wound healing factors, the expectation level of the

Table 5. Analysis of postoperative patient satisfaction, pain, itching, and the observer scale

\begin{tabular}{|lcc|}
\hline Measure & Range & Mean \pm SD \\
\hline Satisfaction (VAS score) & $0-100$ & $58.92 \pm 23.99$ \\
Pain & $0-80$ & $15.31 \pm 22.12$ \\
Itching & $0-80$ & $15.26 \pm 21.70$ \\
Observer scale & $10-32$ & $17.08 \pm 3.5412$ \\
\hline SD, standard deviation; VAS, visual analogue scale. \\
\hline
\end{tabular}

\section{Table 6. Descriptive and correlation results}

\begin{tabular}{|c|c|c|c|c|c|c|c|c|c|c|c|}
\hline Item & $\begin{array}{c}\text { Recog- } \\
\text { nition } \\
\text { degree }\end{array}$ & $\begin{array}{l}\text { Expecta- } \\
\text { tions }\end{array}$ & Age & $\begin{array}{c}\text { Educa- } \\
\text { tion }\end{array}$ & $\begin{array}{l}\text { Previous } \\
\text { cosmetic } \\
\text { surgery }\end{array}$ & $\begin{array}{c}\text { Scar } \\
\text { character } \\
\text { in other } \\
\text { body area }\end{array}$ & $\begin{array}{c}\text { Explana- } \\
\text { tion of } \\
\text { doctor }\end{array}$ & Pain & Itching & $\begin{array}{l}\text { Observer } \\
\text { scale }\end{array}$ & $\begin{array}{l}\text { Satisfac- } \\
\quad \text { tion }\end{array}$ \\
\hline Recognition degree & 1 & & & & & & & & & & \\
\hline Expectations & $-0.598^{\mathrm{a})}$ & 1 & & & & & & & & & \\
\hline Age & 0.011 & -0.088 & 1 & & & & & & & & \\
\hline Education & 0.181 & -0.102 & $-0.344^{\mathrm{a})}$ & 1 & & & & & & & \\
\hline Previous cosmetic surgery & 0.091 & -0.066 & -0.070 & -0.052 & 1 & & & & & & \\
\hline $\begin{array}{l}\text { Scar character in other } \\
\text { body area }\end{array}$ & -0.168 & -0.054 & 0.068 & -0.146 & -0.072 & 1 & & & & & \\
\hline Explanation of doctor & 0.151 & -0.076 & $0.227^{\mathrm{b})}$ & $-0.234^{b)}$ & 0.097 & $-0.258^{b)}$ & 1 & & & & \\
\hline Pain & 0.039 & -0.017 & $0.270^{\text {a) }}$ & $-0.340^{\mathrm{a})}$ & -0.079 & 0.090 & 0.104 & 1 & & & \\
\hline Itching & 0.106 & -0.107 & 0.191 & -0.167 & -0.058 & 0.103 & $0.212^{b)}$ & $0.611^{\mathrm{a})}$ & 1 & & \\
\hline Observer scale & 0.172 & -0.057 & $0.230^{\mathrm{b})}$ & -0.131 & -0.016 & 0.020 & 0.172 & $0.314^{\mathrm{a})}$ & $0.449^{a)}$ & 1 & \\
\hline Satisfaction & $0.280^{\mathrm{a})}$ & $-0.286^{a)}$ & -0.023 & 0.191 & 0.142 & 0.135 & -0.013 & $-0.272^{\mathrm{a})}$ & $-0.342^{\mathrm{a})}$ & $-0.302^{\mathrm{a})}$ & 1 \\
\hline
\end{tabular}


Table 7. Summary of multiple regression analysis on satisfaction in relation to familiarity with healing factors, expectations, observer scale, and itching

\begin{tabular}{|c|c|c|c|c|c|c|}
\hline \multirow{2}{*}{ Model } & \multicolumn{2}{|c|}{ Unstandardized coefficients } & \multirow{2}{*}{$\frac{\text { Standardized coefficients }}{\boldsymbol{\beta}}$} & \multirow{2}{*}{$\mathrm{t}$} & \multirow{2}{*}{ P-value } & \multirow{2}{*}{$\begin{array}{l}\text { Adjusted } \\
\text { R square }\end{array}$} \\
\hline & $\boldsymbol{\beta}$ & Standard error & & & & \\
\hline Constant & 95.293 & 16.679 & & 5.713 & 0.000 & 0.242 \\
\hline Recognition levels & 1.821 & 0.666 & 0.311 & 2.734 & 0.008 & \\
\hline Expectations & -0.169 & 0.114 & -0.170 & -1.479 & 0.143 & \\
\hline Observer scale & -1.980 & 0.720 & -0.292 & -2.751 & 0.007 & \\
\hline Itching & -0.309 & 0.116 & -0.279 & -2.651 & 0.009 & \\
\hline
\end{tabular}

Dependent variable: satisfaction.

Table 8. Summary of multiple regression analysis on satisfaction in relation to familiarity with healing factors, expectations, observer scale, and itching after excluding patients with hypertrophic scars

\begin{tabular}{|c|c|c|c|c|c|c|}
\hline \multirow{2}{*}{ Model } & \multicolumn{2}{|c|}{ Unstandardized coefficients } & \multirow{2}{*}{$\frac{\text { Standardized coefficients }}{\boldsymbol{\beta}}$} & \multirow{2}{*}{$\mathrm{t}$} & \multirow{2}{*}{ P-value } & \multirow{2}{*}{$\begin{array}{l}\text { Adjusted } \\
\mathrm{R} \text { square }\end{array}$} \\
\hline & $\boldsymbol{\beta}$ & Standard error & & & & \\
\hline Constant & 95.877 & 18.147 & & 5.283 & 0.000 & 0.272 \\
\hline Recognition levels & 1.831 & 0.629 & 0.325 & 2.908 & 0.005 & \\
\hline Expectations & -0.296 & 0.114 & -0.284 & -2.590 & 0.011 & \\
\hline Observer scale & -1.467 & 0.905 & -0.153 & -1.622 & 0.109 & \\
\hline Itching & -0.282 & 0.176 & -0.148 & -1.603 & 0.113 & \\
\hline
\end{tabular}

results, itching sensation, and the observer scale as independent variables and the satisfaction level as the dependent variable. As a result, the standardized coefficient $(\beta)$ of the familiarity level with wound healing factors was calculated as 0.311 ; and with an increase in the number of factors, the satisfaction level also increased with statistical significance $(\mathrm{P}=0.008)$. The standardized coefficients $(\beta)$ of the itching sensation and the observer scale were -0.292 and -0.279 , respectively; and with the increase in these values, the satisfaction level decreased with statistical significance $(\mathrm{P}=0.007$ and $\mathrm{P}=0.009$, respectively). The level of expectation regarding the results did not significantly affect the satisfaction level $(\mathrm{P}=0.143)$ (Table 7).

\section{Multiple regression analysis after excluding subjects who developed hypertrophic scars}

We hypothesized that the factors affecting the level of satisfaction would differ between patients who had a hypertrophic scar and those who did not. Therefore, we ran a multiple regression analysis comparing patients with and without hypertrophic scarring.

The standardized coefficient $(\beta)$ of the familiarity with wound healing factors was 0.325 ; and with an increase in the number of factors recognized, the satisfaction level also increased with statistical significance $(P=0.005)$. The standardized coefficient of the expectation level of the results was -0.284; and with the increase in the expectation level, the satisfaction level also de- creased with statistical significance $(\mathrm{P}=0.011)$. The observer scale and itching sensation did not significantly affect the satisfaction level ( $\mathrm{P}=0.109$ and $\mathrm{P}=0.113$, respectively) (Table 8).

\section{DISCUSSION}

According to Ware et al. [6], the factors that affect patient satisfaction include interpersonal manner, technical quality, accessibility/convenience, finances, efficacy/outcomes, continuity of care, physical environment, and availability of care and resources. Clapham et al. [4] modified Ware's taxonomy to make it applicable to the field of plastic surgery; they classified the factors that affect patient satisfaction after cosmetic surgery into three groups: provider-related issues, efficacy/outcome, and all other issues. The efficacy/outcomes were classified into three factors: the aesthetic outcomes, the functional outcomes, and the psychological outcomes. In addition, they conducted a literature review on 178 studies with regard to the factors that affect the patient satisfaction level after plastic surgery. They found that most studies were about cosmetic and functional factors, with the remainder focusing on the general feeling of satisfaction.

In conceiving this study, the authors suspected that, other than the aforementioned factors, there might be personal factors that affect the satisfaction level. In particular, in this study, not only the preoperative familiarity level with wound healing factors, the level of expectation regarding the surgery results, and the rea- 
sons for deciding to undergo esthetic suture were investigated, but also demographic factors such as age and education level, in order to evaluate the influences on the satisfaction level. In this study, age did not affect satisfaction. Chung et al. [7] conducted a study on the prognosis of plastic surgery outpatients and reported that the patient age did not significantly affect satisfaction level. This conclusion coincides with that of this study. In this study, most of the subjects were high school graduates, followed by college graduates and middle school or lower school graduates. According to a study that reported on the expectations of patients regarding orthognathic surgery [8], the satisfaction level did not show differences according to education level; and in the aforementioned studies, the education level likewise did not affect the satisfaction level. The perceived sufficiency of the doctor's explanation did not significantly affect the satisfaction level. This might have been because the explanation was repeated by the same doctor in all cases and the satisfaction level was evaluated six months postoperatively.

The correlation analysis in this study showed that the level of familiarity with factors affecting wound healing; the expectation level of the results; pain; itching sensation; and the observer scale were significantly correlated with the satisfaction level. The multiple regression analysis showed that the level of familiarity with factors influencing the healing process, the itching sensation, and the observer scale independently affected the satisfaction level. The independent evaluation of the expectation regarding the results in relation to the other factors showed that they did not significantly affect the satisfaction level. In clinical situations, the functional and aesthetic results are important factors that affect the level of satisfaction with cosmetic surgery. The satisfaction level seriously deteriorates when a hypertrophic scar develops, and the aesthetic and functional results are significantly worse than compared with those of normal scars $[4,9]$. Therefore, the authors thought that the factors that affect the satisfaction levels of hypertrophic scar patients might differ from the factors that affect the satisfaction levels of patients with flat and linear scars but without hypertrophic scars. To investigate the factors that affect the satisfaction levels of patients without hypertrophic scars, ten hypertrophic scar patients were excluded from the multiple regression analysis. Only the familiarity level with wound healing factors and the expectation level of the results were confirmed to have affected the satisfaction level. In this study, the functional and aesthetic results, such as the itching sensation and the observer scale, significantly affected only ten hypertrophic scar patients. Therefore, the satisfaction levels of most of the patients may not have depended only on cosmetic and functional factors. This is considered an important fact that plastic surgeons, who tend to concentrate on the aes- thetic results of cosmetic surgery, should keep in mind. According to the studies on patient satisfaction conducted by Olson and Laskin [8] and Mira et al. [10], doctors' explanations of the anticipated surgical process, the completed surgical process, and the follow-up management significantly affected the level of satisfaction. Therefore, detailed preoperative explanations of the wound healing process may enhance the familiarity with factors that affect the process, and adjusting any unreasonable expectation levels may enhance patient satisfaction. This result is considered to apply not only to patients who undergo esthetic suture after typical thyroidectomy, but also to general cosmetic surgery patients. As for other types of cosmetic surgery, recognition of the factors that affect the results of the surgery may need to be enhanced.

In multiple regression analysis, to determine the factor that most affected the satisfaction among 4 factors (familiarity with wound healing factors, expectations, observer scale, itching), standardized coefficients were used because standardized coefficients represent the relative influence among the 4 factors that explain satisfaction. That the standardized coefficients were differentiated according to the 4 factors means that when the 4 factors had a simultaneous effect, the factor that had the highest standardized coefficient influenced satisfaction the most.

For this study on the factors that affect the patient satisfaction level after cosmetic surgery, patients who underwent esthetic suture after typical thyroidectomy through transverse cervical incision were selected. This is because, unlike other cancer patients, most thyroid cancer patients are young, the majority of the patients are female, the postoperative incision site is not covered with clothing [11], and the patients and their families are very sensitive to scars because thyroidectomy is not lifethreatening despite being a cancer surgery [12-14]. In the authors' hospital, more and more patients, especially young female patients, elect to undergo esthetic suture after thyroidectomy. In this study, the general factors, including the surgeons, and the cosmetic, functional, and mental factors that can affect the satisfaction level, were better-controlled for than those in other types of cosmetic surgery. Accordingly, it is believed that the influence of personal factors, such as the patient's preoperative expectations of the postoperative satisfaction level were well investigated in this study.

The items in the preoperative survey were devised to evaluate the personal factors that we hypothesized would have an effect on patient satisfaction (demographics, level of familiarity with factors affecting the wound healing process, reason for choosing aesthetic closure, expectation level of the result, level of preoperative explanation). Among those factors, factors that would affect wound healing were designed to include both local factors 
and systemic obstacles [5]. The items in the postoperative survey were designed to evaluate cosmetic and functional results as well as the level of patient satisfaction. Since the cosmetic and functional results significantly affect the satisfaction level, an exact evaluation of the factors is important. In this study, the POSAS was used to evaluate the cosmetic and functional results. This method is deemed useful for linear scar evaluation and burn scar evaluation $[15,16]$. Patients may have more diverse problems than observers recognize, and their own perspectives can influence their quality of life [17]. Functional factors, such as itching sensation and pain, have usually not been evaluated by observers, but they were evaluated in this study using a patient scale, along with the effects of the functional factors on the satisfaction level.

The limitation of this study was that not all the factors that affect the satisfaction level were considered. In an attempt to include as many factors that affect the satisfaction level as possible, cosmetic and functional factors were evaluated. In the multiple regression analysis where the familiarity with factors affecting the wound healing process, the expectation of the results, itching sensation, and the observer scale were independent variables and the satisfaction level was a dependent variable, the adjusted coefficient of determination was calculated to be 0.242 . Accordingly, the integrated effect of the independent variables on the satisfaction level was $24.2 \%$. In the analysis without the hypertrophic scar patients, the effect of the independent variables on the satisfaction level was only $27.2 \%$. This implies that there may be items that significantly influence the satisfaction level other than those that were used in this study. In future studies, these factors may need to be added and evaluated to enhance the satisfaction level.

In conclusion, when the hypertrophic scar patients were excluded, the functional and esthetic results did not affect the satisfaction level; and with an increase in the familiarity with the factors that affect wound healing and decrease in the level of expectation regarding the results, the postoperative satisfaction level improved. Therefore, regardless of the cosmetic and functional results (except with respect to hypertrophic scar patients), sufficient preoperative explanation of the results of cosmetic surgeries and adjustment of the expectation level may contribute to enhanced postoperative patient satisfaction.

\section{REFERENCES}

1. Stewart MG, Porter JP. Outcomes research and facial plastic surgery. Facial Plast Surg 2002;18:73-6.

2. Alsarraf R, Larrabee WF Jr, Anderson S, et al. Measuring cosmetic facial plastic surgery outcomes: a pilot study. Arch Facial Plast Surg 2001;3:198-201.

3. Reich J. Factors influencing patient satisfaction with the results of esthetic plastic surgery. Plast Reconstr Surg 1975;55:5-13.

4. Clapham PJ, Pushman AG, Chung KC. A systematic review of applying patient satisfaction outcomes in plastic surgery. Plast Reconstr Surg 2010;125:1826-33.

5. Broughton G 2nd, Janis JE, Attinger CE. Wound healing: an overview. Plast Reconstr Surg 2006;117:1e-S-32e-S.

6. Ware JE Jr, Snyder MK, Wright WR, et al. Defining and measuring patient satisfaction with medical care. Eval Program Plann 1983;6:247-63.

7. Chung KC, Hamill JB, Kim HM, et al. Predictors of patient satisfaction in an outpatient plastic surgery clinic. Ann Plast Surg 1999;42:56-60.

8. Olson RE, Laskin DM. Expectations of patients from orthognathic surgery. J Oral Surg 1980;38:283-5.

9. Kim JH, Sung JY, Kim YH, et al. Risk factors for hypertrophic surgical scar development after thyroidectomy. Wound Repair Regen 2012;20:304-10.

10. Mira JJ, Tomas O, Virtudes-Perez M, et al. Predictors of patient satisfaction in surgery. Surgery 2009; 145:536-41.

11. Ying AK, Huh W, Bottomley S, et al. Thyroid cancer in young adults. Semin Oncol 2009;36:258-74.

12. Ridgway DM, Mahmood F, Moore L, et al. A blinded, randomised, controlled trial of stapled versus tissue glue closure of neck surgery incisions. Ann R Coll Surg Engl 2007;89: 242-6.

13. Selvadurai D, Wildin C, Treharne G, et al. Randomised trial of subcuticular suture versus metal clips for wound closure after thyroid and parathyroid surgery. Ann R Coll Surg Engl 1997;79:303-6.

14. Amin M, Glynn F, Timon C. Randomized trial of tissue adhesive vs staples in thyroidectomy integrating patient satisfaction and Manchester score. Otolaryngol Head Neck Surg 2009; 140:703-8.

15. Draaijers LJ, Tempelman FR, Botman YA, et al. The patient and observer scar assessment scale: a reliable and feasible tool for scar evaluation. Plast Reconstr Surg 2004;113:1960-5.

16. van de Kar AL, Corion LU, Smeulders MJ, et al. Reliable and feasible evaluation of linear scars by the Patient and Observer Scar Assessment Scale. Plast Reconstr Surg 2005; 116:514-22.

17. Powers PS, Sarkar S, Goldgof DB, et al. Scar assessment: current problems and future solutions. J Burn Care Rehabil 1999;20:54-60. 